\title{
PEMBERDAYAAN MASYARAKAT MELALUI OPTIMALISASI PROGRAM DANA DESA DALAM PERSPEKTIF EKONOMI ISLAM
}

\author{
Muhammad Mujtaba Mitra Zuana*, Muawanah**, Dian Rahmawati*** \\ Institut Pesantren KH. Abdul Chalim, Mojokerto, Indonesia \\ *mujtaba.mitrazuana@gmail.com, **anadarto54@gmail.com,***rdian9815@gmail.com,
}

\begin{abstract}
The village fund provides a very important position for the village to carry out development and community empowerment programs. These include programs for the welfare of the community. Village funds have an important role in improving the economy of rural communities, with effective and efficient use and allocation. This study uses field research with descriptive research methods, the methods used in this study are: observation, structured interviews, and documentation. After the researchers have collected data, the next step is to do the data analysis. The analysis conducted by researchers uses two ways, namely processing the initial data and classifying it and then the next stage of the data will be analyzed. Based on the results of this study it can be concluded that the management of village funds in the village of Kemiri has been running in accordance with existing technical guidelines, so that the development in the village of Kemiri from the existence of village funds has brought considerable changes starting from improving infrastructure facilities, educational advice, health facilities etc. but in the field of empowerment in the village of Kemiri is still not optimal this is due to the lack of community participation in the management of village funds. In the field of development and empowerment, the community is only involved in planning and implementation, but in terms of accountability and evaluation of the community village fund program, it has not been directly involved.
\end{abstract}

Keywords: Optimization Strategy, Community Empowerment, Kemiri Village 


\begin{abstract}
Abstrak
Dana desa memberikan posisi yang sangat penting bagi desa untuk melaksanakan program pembangunan dan pemberdayaan masyarakat. Ini termasuk program untuk kesejahteraan masyarakat. Dana desa memiliki peran penting dalam meningkatkan perekonomian masyarakat pedesaan dengan penggunaan dan alokasi yang efektif dan efisien. Penelitian ini menggunakan penelitian lapangan dengan metode penelitian deskriptif. Metode yang digunakan dalam penelitian ini adalah: observasi, wawancara terstruktur, dan dokumentasi. Setelah peneliti mengumpulkan data, langkah selanjutnya adalah melakukan analisis data. Analisis yang dilakukan peneliti menggunakan dua cara yaitu mengolah data awal dan mengklasifikasikannya kemudian pada tahap selanjutnya data tersebut akan dianalisis. Berdasarkan hasil penelitian dapat disimpulkan bahwa pengelolaan dana desa di Desa Kemiri sudah berjalan sesuai dengan juknis yang ada, sehingga pembangunan di Desa Kemiri dari adanya dana desa telah mendatangkan hasil yang cukup banyak. Perubahan mulai dari perbaikan sarana prasarana, penyuluhan pendidikan, sarana kesehatan dan lain-lain. Namun dalam bidang pemberdayaan di desa kemiri masih belum optimal hal ini disebabkan masih kurangnya partisipasi masyarakat dalam pengelolaan dana desa. Di bidang pembangunan dan pemberdayaan, masyarakat hanya dilibatkan dalam perencanaan dan pelaksanaan, namun dalam hal akuntabilitas dan evaluasi program dana desa masyarakat belum dilibatkan secara langsung.

Kata Kunci: Strategi Optimalisasi, Pemberdayaan Masyarakat, Desa Kemiri
\end{abstract}


Muhammad Mujtaba, dkk: Pemberdayaan Masyarakat Melalui Optimalisasi Program Dana Desa

\section{PENDAHULUAN}

Bentuk kepedulian pemerintah terhadap pengembangan wilayah pedesaan adalah dengan adanya anggaran pembangunan dan pemberdayaan secara khusus yang dicantumkan dalam Anggaran Pendapatan dan Belanja Daerah (APBD) untuk membangun wilayah pedesaan yakni dalam bentuk Dana Desa (DD) (Kaloh, 2007). Sejak tahun 2015, pemerintah telah memberikan Dana Desa (selanjutnya akan disebut dengan DD) kepada desa yang bersumber dari APBN yang ditransfer melalui APBD kabupaten/ kota. Desa Kemiri pada tahun 2016 memperoleh dana desa sebesar Rp. 622.543.000 yang di anggarkan untuk bidang pembangunan dan pemberdayaan dan pada tahun 2017 Desa Kemiri memperoleh dana desa sebesar Rp.793.919.000, meningkat dari tahun sebelumnya. Dan pada tahun 2018 sebesar Rp. 673.151.000.

Dana desa merupakan salah satu alat untuk membantu terlaksananya pembangunan desa dan pemberdayaan masyarakat dalam upaya meningkatkan perekonomian masyarakat. Dengan adanya dana desa ini, diharapkan agar dapat membantu masyarakat dalam segi kebutuhan, pembangunan sarana dan prasarana, serta dapat mengembangkan potensi ekonomi lokal yang didasarkan atas kondisi dan potensi desa. Namun, dalam pelaksanaan penggunaan dana desa masih dirasakan belum optimal dikarenakan belum memadainya kapasitas dan kapabilitas pemerintah desa dan belum terlibatnya peran serta masyarakat secara aktif dalam pengelolaan program dana desa.

Berdasarkan dari fenomena diatas, maka fokus utama dalam penelitian ini adalah melihat bagaimana partisipasi dan respon masyarakat desa Kemiri dalam pelaksanaan program pemberdayaan melalui dana desa, bagaimana pemberdayaan masyarakat sebelum dan sesudah adanya dana desa, bagaimana upaya yang dilakukan pemerintah desa kemiri dalam meningkatkan pemberdayaan masyarakat dengan adanya program dana desa, dan bagaimanakah pemberdayaan masyarakat dalam perspektif Ekonomi Islam.

\section{LANDASAN TEORITIS}

\section{Strategi}

Strategi bersumber dari kata Yunani Klasik, yakni "strategos” (jenderal), yang pada dasarnya diambil dari pilahan kata-kata Yunani untuk "pasukan" dan "memimpin". Penggunaan kata kerja Yunani yang berhubungan dengan "strategos" ini dapat diartikan sebagai perencanaan dan pemusnahan musuh-musuh dengan menggunakan cara yang efektif berlandaskan sarana- sarana yang dimiliki (Masitoh \& Laksmi Dewi, 2009). 
Strategi juga bisa diartikan langkah-langkah yang harus dilalui untuk mencapai target jangka panjang yang akan di inginkan. Upaya pemerintah mewujudkan desa sejahtera dan mandiri merupakan strategi membangun ekonomi pinggiran yang memungkinkan warga desa dan kelompok masyarakat miskin di desa memperoleh apa yang mereka inginkan dan perlukan bagi dirinya maupun keluarganya. Strategi ini merupakan upaya untuk menolong mereka yang mencari dan menggantungkan kehidupan di desa untuk memperoleh lebih banyak manfaat dari hasil pembangunan terutama dari program dana desa.

\section{Dana Desa}

Dana Desa adalah dana yang bersumber dari Anggaran Pendapatan dan Belanja Negara yang diperuntukan bagi Desa yang di transfer melalui Anggaran Pendapatan dan Belanja Daerah Kabupaten/kota dan diprioritaskan untuk pelaksanaan pembangunan dan pemberdayaan masyarakat desa (Supriadi \& Dadang Sholihin, 2003).

Penganggaran Dana Desa dalam Anggaran Pendapatan dan Belanja Negara ditentukan 10 persen dari dan di luar Dana Transfer Daerah yang dialokasikan di dalam Anggaran Pendapatan dan Belanja Negara (APBN) secara bertahap (Sutoro, 2016). Contoh, apabila belanja Transfer Daerah di dalam APBN tahun 2019 adalah Rp. 810 triliun, maka besaran Dana desa yang harus disediakan oleh pemerintah pusat pada tahun 2019 adalah Rp. 81 triliun, yaitu merupakan hasil perhitungan 10 persen dikalikan dengan belanja Transfer Daerah.

\section{Pemberdayaan Masyarakat}

Secara konseptual, pemberdayaan atau pemberkuasaan (empowerment), berasal dari kata 'power' (kekuasaan atau keberdayaan) (Suharto, 2014). Pemberdayaan adalah upaya untuk membangun kemampuan masyarakat, dengan mendorong, memotivasi, membangkitkan kesadaran akan potensi yang dimiliki dan berupaya untuk meningkatkan serta mengembangkan potensi tersebut menjadi nyata (Nurman, 2015). Pemberdayaan masyarakat adalah upaya untuk meningkatkan harkat dan martabat golongan masyarakat yang sedang dalam kondisi miskin, sehingga mereka dapat melepaskan diri dari perangkap kemiskinan dan keterbelakangan (Zubaedi, 2013).

Falsafah pemberdayaan masyarakat dapat dikatakan sebagai kerjasama dengan masyarakat untuk meningkatkan taraf hidup mereka. Pemberdayaan semakin popular dalam konteks pembangunan dan pengentasan kemiskinan yang terjadi pada saat ini. Konsep pemberdayaan yang diusung adalah untuk melihat yang tidak berdaya atau lemah (powerless) (M. Anwas, 2014). Oleh karena itu, pemberdayaan sangat berpengaruh terhadap proses pembentukan masyarakat yang sejahtera (Sulistiani, 
2004).

\section{Kerangka Pemikiran}

Pemikiran awal yang melandasi peneliti untuk melakukan penelitian ini adalah berangkat dari isu utama yaitu belum optimalnya program dana desa dalam pemberdayaan masyarakat di desa Kemiri. Dana desa merupakan salah satu alat untuk membantu terlaksananya pembangunan desa dan pemberdayaan masyarakat dalam upaya meningkatkan perekonomian masyarakat. Dengan adanya dana desa ini, diharapkan agar dapat membantu masyarakat dalam segi kebutuhan, pembangunan sarana dan prasarana, serta dapat mengembangkan potensi ekonomi lokal yang didasarkan atas kondisi dan potensi desa. Namun, pengelolaan program dana desa di desa Kemiri dalam pemberdayaan perekonomian masyarakat bisa dikatakan belum optimal dikarenakan belum memadainya kapasitas dan kapabilitas pemerintah desa dan belum terlibatnya peran serta masyarakat secara aktif dalam pengelolaan dana desa.

\section{METODE}

Jenis penelitian yang digunakan dalam penelitian ini adalah penelitian kualitatif, menggunakan penelitian lapangan dengan metode penelitian deskriptif, cara yang digunakan dalam penelitian ini yaitu: observasi, wawancara terstruktur, serta dokumentasi. Setelah peneliti mengumpulkan data kemudian dilakukan langkah selanjutnya yaitu Analisis data. Analisa yang peneliti lakukan menggunakan dua cara yaitu mengolah data awal dan mengklasifikasikanya kemudian tahap berikutnya data tersebut akan dianalisa (Manjta, 2005).

Pada penelitian ini yang menjadi lokasi penelitian adalah desa Kemiri kecamatan Pacet kabupaten Mojokerto. Sedangkan triangulasi dalam penelitian ini menggunakan triangulasi sumber data. Triangulasi sumber data adalah menggali kebenaran informai tertentu melalui berbagai metode dan sumber perolehan data (Moleong, 2012). Selain melalui wawancara dan observasi dengan perangkat desa, BPD dan tokoh masyarakat desa Kemiri, peneliti juga menggunakan observasi terlibat (participant obervation), dokumen tertulis, arsif, dokumen sejarah, catatan resmi, catatan atau tulisan pribadi dan gambar atau foto yang bisa di dapatkan di kantor desa Kemiri. Tentu masing-masing cara itu akan menghasilkan bukti atau data yang berbeda, yang selanjutnya akan memberikan pandangan (insights) yang berbeda pula mengenai fenomena yang diteliti. Berbagai pandangan itu akan melahirkan keluasan pengetahuan untuk memperoleh kebenaran handal. 


\section{HASIL DAN PEMBAHASAN}

\section{Strategi Optimalisasi Progam Dana Desa Melalui Pemberdayaan Masyarakat Desa Kemiri Kec. Pacet Kab. Mojokerto}

Progam Dana desa dapat dilakukan dengan mengoptimalkan program pemberdayaan masyarakat yang ada di desa Kemiri. Mengoptimalkan pembangunan infrastruktur desa dengan program pemberdayaan masyarakat akan membuat masyarakat berperan serta dalam perbaikan dan pembangunan yang dilakukan di desa.

Pemberdayaan masyarakat di desa Kemiri sebelum adanya dana desa sangat terbatas dalam segi pendanaan dan program yang akan dilaksanakan oleh pemerintah desa. Pemberdayaan masyarakat dan pembangunan infrastruktur desa Kemiri dikala itu bersifat swadaya gotong royong masyarakat dengan sukarela.

Peran dana desa dirasa sangat membantu dalam pemberdayaan dan pembangunan infrastruktur di desa Kemiri, dengan adanya dana desa pemerintah dapat menjalankan program-program yang telah disepakati bersama antara pemerintah desa, masyarakat dan lembaga lembaga yang ada di desa Kemiri. Pemberdayaan masyarakat setelah adanya dana desa pembangunan dan pemberdayaan mulai berjalan dengan lancar, dalam artian pembangunan terus berjalan dalam membenahi infrastruktur desa seperti jalan-jalan yang rusak, setelah adanya dana desa dapat diperbaiki. Beberapa sarana infrastruktur, sarana pendidikan, sarana kesehatan yang tadinya rusak sekarang sudah bagus.

Setelah adanya dana desa pembangunan serta pemberdayaan masyarakat desa Kemiri dapat meningkat. Contoh pemberdayaan desa Kemiri dari segi ekonomi dapat dilihat dengan diadakannya Bumdes berupa pengelolaan sampah organik dan non organik yang nantinya akan mendatangkan lapangan usaha untuk masyarakat sekitar dalam membuat kerajinan dari sampah non organik, meskipun dalam kenyataanya belum dapat dirasakan secara penuh oleh masyarakat.

Dalam konteks pekerjaan sosial pemberdayaan yang dilaksanakan Pemerintah desa Kemiri dengan menggunakan pendekatan tiga aras yaitu:

a) Aras Mikro, dimana pemerintah desa Kemiri dalam memberdayakan masyarakat di desa Kemiri telah berhasil untuk melakukan pelatihan pengelolaan sampah, baik untuk sampah organik maupun non organik. Pelatihan ini dilakukan agar sampah di desa Kemiri bisa diolah dan bisa menghasilkan sesuatu yang bermanfaat seperti sampah organik menjadi pupuk kompos dan sampah non organik menjadi kerajinan unik yang dapat menghasilkan penghasilan untuk masyarakat. Dan pada akhirnya pelatihan ini bisa menjadi sebuah kelompok 
yang bernama bank sampah intafa'a yang dinaungi oleh BUMDes Kemiri.

b) Aras Mezzo, pemerintah Desa Kemiri menggunakan kelompok sebagai media intervensi, Pendidikan dan pelatihan, dan dinamika kelompok. Hal ini terwujud dalam pemberdayaan PKK yang pada kelompok ini diberikan penyuluhan dan pelatihan tata boga untuk meningkatkan ketrampilan dalam memasak. Diharapkan dengan pelatihan ini dapat meningkatkan kreatifitas ibu pkk dalam mengolah makanan dan dapat menghasilkan suatu produk unggulan khas desa Kemiri. Pelatihan dan penyuluhan pemberdayaan perempuan ini juga didanai dari Dana Desa.

c) Aras Makro, pada pendekatan aras makro ini terwujud dengan terlaksananya Musyawarah Dusun dan Musyawarah Desa. Dapat dilihat bahwa pemerintah dan masyarakat selalu bekerjasama, bermusyawarah dan menyepakati usulan masyarakat membentuk program dalam upaya pemenuhan kebutuhan msyarakat desa.

Pada pemberdayaan yang berlangsung di desa Kemiri, tujuan dari pemberdayaan dalam meningkatkan kemandirian masyarakat mulai terlaksana pada masyarakat. Hal ini ditunjukan dengan kemampuan masyarakat dalam menganalisis kebutuhan masyarakat sendiri untuk bersama disepakati dalam Musdus dan Musrenbangdes sehingga pembangunan dapat terlaksana dan kebutuhan masyarakat dapat terpenuhi.

Jika melihat dari teori yang dikemukakan oleh Menteri DPDTT menjelaskan tentang cara mengoptimalkan pengelolaan dana desa. Pemerintah desa Kemiri bisa menerapkan strategi ini untuk pengoptimalan dana desa melalui pemberdayaan masyarakat. Beberapa strategi untuk mengoptimalkan progam dana desa diantaranya yaitu:

a) pemenuhan asas transparansi.

Dana desa harus diketahui seluruh masyarakat desa Kemiri, bukan hanya pada aspek kuantitas atau jumlah, tetapi juga pada aspek distribusi atau peruntukkan. Berapa dana desa yang diterima, digunakan untuk apa, serta apa manfaatnya, masyarakat desa Kemiri wajib mengetahuinya. Bahkan karena tegasnya, pemerintah desa diharuskan membuat pengumuman atau mempublikasikannya kepada masyarakat di ruang publik. Dengan langkah ini, penggunaan dana desa betul-betul diketahui oleh masyarakat desa Kemiri, dan karenanya pemerintah desa akan terhindarkan dari kecurigaan atau sakwasangka. Misalnya saja dengan membuat banner tentang Apbdes tahun berjalan di tempat umum yang bisa dibaca oleh masyarakat umum. Pemerintah 
desa Kemiri juga diharuskan mensosialisasikan program yang didanai dari dana desa kepada masyarakat, karena hal ini sangat penting untuk memberikan informasi kepada masyarakat akan berapa jumlah dana yang turun ke desa, dan digunakan untuk apa saja dana tersebut.

b) peningkatan pembangunan Desa

Pembangunan mencakup dua aspek yaitu fisik material dan mental spiritual. Kedua aspek ini tidak boleh ada yang terabaikan dalam perencanaan penggunaan desa. Lingkungan fisik dibangun bersamaan dengan pembangunan mental. Oleh karena itu, penting bagi pemerintah desa Kemiri untuk melibatkan semua unsur masyarakat dalam musyawarah perencanaan pembangunan desa. Kepala Desa bersama aparaturnya, sekretaris Desa, anggota BPD (Badan Permusyawaratan Desa), tokoh agama, lembaga adat, ormas keagamanaa, kelompok tani, kelompok pengrajin, penyedia jasa, pihak penyelenggara pendidikan, semua dilibatkan dalam musyawarah. Bila perlu, instansi terkait dilibatkan guna mendapatkan berbagai masukan dan tawaran program demi kemajuan desa. Dengan langkah ini, program pembangunan yang direncanakan pemerintah desa dapat sesuai dengan kebutuhan. Dan disetiap rapat musdus ataupun musdes semua masyarakat harus dilibatkan secara langsung agar penyampaian aspirasi masyarakat bisa ditampung dengan baik dan pembangunan yang dijalankan sesuai dengan kebutuhan masyarakat desa Kemiri.

c) memaksimalkan pemberdayaan masyarakat desa Kemiri.

Kegiatan ini ditujukan untuk meningkatkan kapasitas dan kapabilitas masyarakat desa Kemiri dengan mendayagunakan potensi dan sumber dayanya sendiri sehingga desa Kemiri dapat mandiri. Harus diakui bahwa salah satu persoalan yang dihadapi oleh desa adalah rendahnya kualitas SDM. Sehingga, melalui kegiatan pemberdayaan, dana desa dapat bermanfaat untuk meningkatkan kapasitas aparatur desa maupun masyarakat. Seperti pemberdayaan kelompok perempuan diberikan pelatihan-pelatihan yang bermanfaat seperti membuat kerajinan atau mengolah makanan yang nantinya bisa menjadi sumber pemasukan untuk masyarakat, petani dapat diberikan penyuluhan serta bantuan pemberdayaan berupa bibit dan alat-alat pertanian, demikian pula tukang kayu, pengrajin tenun, pedagang roti dan kue tradisional, kelompok pelestari lingkungan, petani rumput laut, pengelola sanggar budaya, dan lain sebagainya. Dalam konteks ini, penting bagi pemerintah desa untuk membentuk koperasi unit desa (KUD) dan badan usaha milik desa (BUMDes). Melalui KUD, anggaran pemberdayaan dapat dikelola secara profesional, transparan, dan akuntabel, dan melalui BUMDes berbagai 
hasil produksi masyarakat dapat dikelola dan di distribusikan sehingga lebih berguna dan bermanfaat untuk kemajuan desa.

Jika ketiga prioritas tersebut dapat diwujudkan oleh pemerintah desa Kemiri, maka desa pasti akan semakin maju.

Dilihat dari pelaksanaan program dana desa melalui pemberdayaan masyarakat di desa Kemiri, tujuan dari dana desa ini belum tersentuh secara menyeluruh. Hal ini dikarenakan peran dan kontribusi masyarakat belum dilibatkan secara penuh. Pengerjaan pembangunan infrastruktur dan pemberdayaan masyarakat hanya melalui perencanaan dan pelaksanaannya saja, akan tetapi pertanggung jawaban atau pengawasan dari masyarakat sendiri kurang.

Beberapa upaya yang dilakukan oleh pemerintah desa Kemiri dalam mengoptimalkan progam dana desa dan merupakan bentuk aspirasi masyarakat desa Kemiri yang sudah terealisasi dari tahun 2016-2018 sebagai berikut:

\section{a) Pembangunan infrastruktur desa Kemiri}

Pembangunan infrastruktur merupakan hal yang diharapkan oleh masyarakat desa Kemiri, mulai dari pembangunan jalan, jembatan, goronggorong saluran air, dan tembok penahan tanah. Dengan pembangunan infrastruktur di segala lini di desa Kemiri maka hal ini sangat menentukan kemajuan dan kemandirian dari desa Kemiri sendiri. Seperti contoh para petani, dengan dibangunnya tembok penahan tanah untuk sarana irigasi mereka bisa mengaliri sawah mereka dengan mudah.

b) Peningkatan kapasitas kelompok tani

Dalam rangka meningkatkan kesejahteraan petani, pemerintah desa Kemiri menyetujui usulan atau aspirasi masarakat dalam rapat musdes yaitu dengan mengadakan pelatihan peningkatan kapasitas kelompok tani. Di desa Kemiri sudah dibentuk kelompok tani akan tetapi belum aktif dengan baik, dimana anggotanya belum memanfaatkan lembaga tersebut untuk meningkatkan kinerja usaha tani. Setelah mengikuti pelatihan ini petani dituntut untuk mampu bekerjasama dibidang ekonomi secara berkelompok dan mampu meningkatkan efektivitas dan efesiensi usaha tani sehingga petani di desa Kemiri menjadi sejahtera. Kegiatan ini juga bertujuan untuk meningkatkan hasil panen para petani di desa Kemiri. Pada kegiatan ini pemerintah desa menganggarkan senilai Rp. 5.000.000 untuk peningkatan kapasitas kelompok tani. 
c) Pelatihan pengelolaan sampah skala rumah tangga

Pengelolaan sampah yang dapat dilakukan pada skala rumah tangga salah satunya yaitu dengan melalui Bank sampah. Bank sampah merupakan suatu konsep pengumpulan sampah kering yang berasal dari rumah untuk memaksimalkan partisipasi warga dan menambah nilai ekonomis dari sampah. Tujuan dari bank sampah sebagai solusi reduksi sampah di tingkat masyarakat karena kemampuannya yang menjadi bagian dari sistem rantai pengumpulan sampah terintegrasi. Dari pelatihan ini masyarakat desa Kemiri tahu jenis-jenis sampah dan cara memilahnya dan menjadikan sampah sebagai nilai ekonomis.

d) Penyelenggaraan Kesehatan desa

Kesehatan memang investasi yang harus di upayakan, diperjuangkan dan ditingkatkan oleh setiap masyarakat. Dalam rangka meningkatkan kesehatan masyarakat desa Kemiri, maka pemerintah desa menganggarkan anggaran untuk kesehatan. Penyelenggaraan kesehatan ini meliputi pengobatan, penimbangan, pengecekan kadar gula, kolesterol untuk orang tua atau lansia di desa Kemiri. Anggaran ini juga digunakan untuk posyandu balita yang diadakan setiap bulannya di dusun-dusun. Kegiatan posyandu balita meliputi penimbangan berat badan balita, pengukuran tinggi badan, imunisasi dan pemberian vitamin. Pada penyelenggaraan kesehatan, pemerintah desa Kemiri menganggarkan Rp. 10.000.000 dan pemantauan gizi balita sebesar Rp. 12.100.000.

e) Penyertaan modal BUMDes

Penyertaan modal BUMDes memang sangat diperlukan, hal ini di harapkan untuk menambah modal BUMDes yang ada di desa Kemiri dan meningkatkan perekonomian desa. BUMDes desa Kemiri sudah berjalan dibidang perekonomian seperti Bank sampah intafa'a desa kemiri, usaha simpan pinjam dan penyewaan alat berat. Hal ini harus tetap didukung dengan modal yang banyak agar Bumdes desa Kemiri bisa maju dan berkembang, sehingga akan meningatkan pendapatan asli desa. Pada tahun 2020 pemerintah menambah penyertaan modal bumdes sebesar 150 juta untuk wahana wisata jembatan gantung di desa Kemiri. Pemerintah desa Kemiri ingin mengembangkan potensi desa untuk dijadikan desa wisata yang bertujuan untuk memberdayakan masyarakat dan mengentaskan kemiskinan di desa.Karena wisata dirasa membuahka

f) Menggiatkan progam PKK melalui usaha produksi rumahan dan ketrampilan. 
Dari segi pemberdayaan ekonomi pemerintah desa telah mengupayakan peningkatan salah satunya yaitu dengan mengadakan pelatihan usaha produksi rumahan seperti pembuatan es cream telo atau pengolahan ubi telo dan sayur-sayuran seperti bayam, wortel menjadi kripik dan masih banyak lagi. Di desa Kemiri sudah mempunyai industri pabrik yang mengolah berbagai makanan khas umbi-umbian, dan sekarang sudah cukup terkenal karena sudah tersebar ke berbagai pelosok indonesia bahkan pernah ekspor ke luar negri seperti belanda. Industri rumahan ini berlabel "kripik sehati”. Dari sini pemerintah desa ingin mengembangkan ketrampilan ibuibu dalam mengolah makanan dan memiliki tujuan yang sangat positif dalam meningkatkan perekonomian masyarakat desa Kemiri. Dalam pemberdayaan ini pemerintah desa mengalokasikan dana yang berasal dari dana desa sebesar Rp. 14.000.000 pada tahun 2017 dan Rp. 13.568.000 pada tahun 2018. Hal ini disesuaikan dengan RAB kebutuhan setiap kegiatan. Pada tahun 2020 pemerintah desa merencanakan mengadakan study tour untuk ibu-ibu PKK ke tempat-tempat industri yang bisa memberikan pengalaman dan pengetahuan dalam meningkatkan ketrampilan.

g) Sosialiasi penggunaan dana desa

Dengan diturunkan dana milyaran rupiah ke desa, maka untuk menghindari penyalahgunaan dana desa yaitu dengan sosialisasi dana desa. Dengan sosialisasi dana desa masyarakat diberi keleluasaan dalam mengakses semua program yang terbiayai dari dana desa. Masyarakat dilibatkan secara langsung baik itu melalui perencanaan, pembangunan ataupun pengawasan dan pertanggungjawaban. Dengan hal ini penyalahgunaan dana desa bisa diatasi.

h) Pengembangan program PAMSIMAS (Penyediaan Air minum dan Sanitasi Berbasis Masyarakat)

PAMSIMAS adalah salah satu program yang dilaksanakan oleh pemerintah Indonesia dengan dukungan Bank Dunia yang ditujukan untuk wilayah pedesaan. Program pamsimas ini bertujuan untuk memfasilitasi warga agar dapat mengakses pelayanan air minum yang bersih dan sarana sanitasi serta meningkatkan penerapan perilaku hidup bersih dan sehat masyarakat desa Kemiri.

Dari semua program yang sudah terealisasi dari dana desa, ada beberapa program yang memang belum terealisasi secara optimal. Untuk kedepannya pemerintah desa Kemiri akan terus mengupayakan agar progam dana desa melalui pemberdayaan masyarakat bisa terealisasi secara optimal dan baik, maka dari itu diperlukan strategi yang bagus untuk mengoptimalkan progam dana desa di desa Kemiri. 
Dari program dana desa yang ada di desa Kemiri, BUMDES (Badan Usaha Milik Desa) adalah salah satu usaha perekonomian desa yang dianggap paling optimal. Bisa dilihat BUMDES desa Kemiri dari tahun ke tahun terus meningkat pedapatannya. Hal ini dikarenakan usaha yang dijalankan juga semakin banyak. Setiap tahun pemerintah desa selalu menganggarkan untuk penguatan modal BUMDES ini. Tujuan dari pendirian BUMDES Kemiri ini adalah untuk mengembangkan usaha dan meningkatkan perekonomian desa yaitu dilakukan dengan cara memberdayakan masyarakat yang ada di desa. Pemberdaaan masanrakat sendiri merupakan model pembangunan berakar kerakyatan adalah upaya untuk meningkatkan harkat dan martabat sebagian masyarakat kita yang masih terperangkap pada kemiskinan dan keterbelakangan. Keberadaan BUMDES kemiri sangat diharapkan untuk dirasakan manfaatnya oleh masarakat desa Kemiri. Beberapa usaha BUMDES Kemiri yang sudah berjalan dan dapat dirasakan manfaatnya yaitu:

\section{a) Bank sampah}

Bank sampah merupakan konsep pengumpulan sampah kering (misalnya kertas, karton, kaleng, majalah dan sampah plastik lainnya) yang berasal dari rumah untuk memaksimalkan partisipasi warga dan menambah nilai ekonomis dari sampah. Adapun tujuan dari bank sampah yaitu sebagai solusi reduksi sampah di tingkat masyarakat karena kemampuannya yang menjadi bagian dari sistem rantai pengumpulan sampah yang terintegrasi.

Di desa kemiri sampah rumah tangga dipilah mulai rumah masingmasing kemudian disetor, ditimbang, dan dicatat didalam buku tabungan hasil sampah yang disetorkan. Oleh petugas bank sampah, sampah diangkut dari pelapak kecil, ke pelapak besar. Proses pengangkutan dilakukan oleh pelapak kecil ke tempat pengumpulan sampah pelapak besar. Dari situlah kemudian bank sampah mendapatkan keuntungan. Setelah pengangkutan, sampah masuk ke dalam proses daur ulang.

Melalui bank sampah, masyarakat bisa mendapatkan penghasilan tambahan untuk kebutuhan rumah tangga, seperti uang jajan anak dan sebagainya. Bisnis ini bisa dilakukan ole para rumah tangga atau siapapun yang mengingkinkan penghasilan tambahan untuk kebutuhan rumah tangga dan lingkungan yang sehat. Semakin banyak warga desa Kemiri yang menyetorkan sampahnya ke bank sampah, akan semakin banyak pula penyerapan sampah yang ada diwilayah desa Kemiri. Keuntungan juga tidak hanya saat menyetorkan sampah, tetapi juga saat sampah sudah didaur ulang menjadi produk, penyetor akan mendapatkan $10 \%$. Sebagian masyarakat memilih utuk memilahnya saja dan sebagian memilih mendaur ulang menjadi produk yang 
bermanfaat dan kemudian dijual.

b) Unit usaha jasa sewa alat berat

Bumdes kemiri juga menyewakan sewa alat berat berupa excavator. Usaha ini dijalankan dengan tujuan utamanya untuk kebutuhan domestik desa Kemiri sendiri. Selanjutnya persewaan ini bisa untuk melayani masyarakat atau pengusaha dari desa lain yang membutuhkan jasa alat berat. keuntungan usaha alat berat ditentukan dari banyaknya orang yang menyewa dalam satu hari. Misalkan dalam satu hari ada 5 orang penyewa maka perhitungan keuntungan kotor sehari sebesar 5 juta. Dengan asumsi jangka waktu sewa selama 10 jam. Akan tetapi usaha sewa alat berat yang dinaungi oeh bumdes Kemiri ini tak luput dari resiko, diantaranya sepi pelanggan, persaingan yang tinggi dan resiko terjadinya kerusakan.

c) Simpan pinjam

Bumdes kemiri juga memiliki usaha simpan pinjam. Kegiatan simpan pinjam ini banyak membantu dalam perekonomian masyarakat di desa untuk maju dan berkembang bersama. Bunga yang diberikan oleh BUMDes Kemiri tidak sebesar bunga pinjaman yang diberikan oleh pihak bank. Sehingga hal ini tentunya akan meringankan beban peminjamnya. Selain itu, karena dikelola oleh masyarakat dan akan kembali ke masyarakat maka pengelolaan akan bersifat lebih fleksibel. Segala persyaratan dan anggunan yang diajukan juga tidak serumit saat mengajukan pinjaan kepada pihak bank. Kemudahankemudahan ini hanya bisa dinikmati oleh masarakat desa Kemiri melalui BUMDes.

Usaha BUMDes kemiri akan ditambah terus seiring berjalannya waktu, pemerintah desa akan meningatkan pendapatan asli desa dengan memajukan bumdes kemiri. Pada tahun 2020 bumdes desa Kemiri akan membangun wisata jembatan gantung dan wisata mendaki gunung. Hal ini juga untuk meningkatkan perekonomian warga desa Kemiri dan membuat desa Kemiri semakin maju.

\section{Pemberdayaan Masyarakat Dalam Perspektif Ekonomi Islam}

Pemberdayaan masyarakat Islam adalah suatu proses atau tindakan yang terjadi di Indonesia dengan memberikan rasa tanggung jawab terhadap konteks ekonomi. Dengan demikian masyarakat muslim dituntut untuk lebih keras untuk bekerja, berinteraksi, dan berwirausaha.

Berdasarkan ayat Ar-Ra'd ayat 11 yang menyebutkan bahwa Tuhan tidak akan 
merubah keadaan mereka, selama mereka tidak merubah sebab-sebab kemunduran mereka. Sejalan dengan teori pemberdayaan masyarakat yang mana melalui pemberdayaan masyarakat dapat memiliki inisiatif dan kemampuan untuk mengelola sendiri sumber daya mereka. Sehingga dengan mereka dapat mengelola dan membentuk penggalian kemampuan pribadi, kreatifitas, kompetensi dan daya pikir dapat merubah kehidupannya pula dengan kemampuan dan keahlian yang dimiliki.

Pemberdayaan yang dilakukan pemerintah desa bersama masyarakat merupakan wujud keinginan masyarakat desa Kemiri untuk lebih maju dan berkembang. Partisipasi masyarakat meningkat dengan adanya program dana desa dalam pembangunan dan pemberdayaan masyarakat yang bertujuan menciptakan kemaslahatan umat, kemandirian dan kepribadian yang bertanggungjawab. Pemerintah desa Kemiri sangat terbantu dengan adanya dana desa dalam pembangunan sarana dan prasarana desa serta berjalnnya program pemberdayaan masyarakat.

Jika melihat dari teori yang dikemukakan oleh Saefudin menjelaskan adanya nilai-nilai dasar sistem ekonomi. Pemerintah desa dalam pengelolaan dana desa pada pemberdayaan masyarakat sudah menerapkan sistem ekonomi Islam dalam pemberdayaan yaitu kepemilikan, keseimbangan dan keadilan.

a) Kepemilikan

Pemerintah desa Kemiri dapat memanfaatkan dan bukan menguasai secara mutlak dana desa melainkan harus digunakan secara bijak dan bertanggung jawab dalam upaya meningkatkan pemberdayaan masyarakat agar masyarakat dapat menjadi lebih baik secara perekonomian dan kualitas hidup.

b) Keseimbangan

Konsep keseimbangan yang tidak hanya mengukur kebaikan dari hasil usaha yang diarahkan untuk dunia dan akhirat saja, tetapi berkaitan juga tentang kepentingan (kebebasan) perorangan dengan kepentingan umum yang harus dipelihara antara keseimbangan antara hak dan kewajiban dan kewajiban yang harus terealisasikan. Dalam wawancara dengan bapak Sutrisno selaku Ketua BPD desa Kemiri mengatakan bahwa pemerintah desa Kemiri pada pengelolaan dana desa bersama masyarakat dan lembaga yang ada selalu bermusyawarah dalam menentukan arah pembangunan dan pemberdayaan melalui program dana desa. Dapat disimpulkan dari hasil wawancara berdasar pada teori diatas menunjukkan bahwa konsep kesimbangan pada pengelolaan dana desa didesa Kemiri telah terealisasi dilihat dari pembangunan dan pemberdayaan yang dilakukan pemerintah 
Muhammad Mujtaba, dkk: Pemberdayaan Masyarakat Melalui Optimalisasi Program Dana Desa

desa Kemiri.

c) Keadilan

Pada konsep keadilan ini dinyatakan oleh Yusuf Qardhawi bahwasanya Ruh sistem Islam merupakan pertengahan yang adil dimana disebutkan dalam Al-Qur'an paling banyak setelah Allah dan ilmu pengetahuan baik keadilan dalam aspek sosial, politik maupun ekonomi (Abbas, 2012). Berdasarkan teori diatas pemerintah desa seharusnya dapat melaksanakan keadilan yang merata bagi masyarakat selaku objek dari pemberdayaan. Dari wawancara dengan bapak Suwito selaku masyarakat desa Kemiri mengatakan bahwa pemberdayaan yang dilaksanakan pemerintah desa berdasar dari kesepakatan bersama dalam pemenuhan kebutuhan masyarakat, dari usulan-usulan yang diambil dari perwakilan setiap RT/ Dusun yang berpartisipasi pada musyawarah desa. Berdasarkan teori dan wawancara yang ada terkait keadilan dapat disimpulkan bahwa keadilan dalam pengelolaan dana desa dalam pembangunan dan pemberdayaan masyarakat dapat dilihat dari pemenuhan kebutuhan masyarakat sesuai usulan dari perwakilan masyarakat desa.

\section{SIMPULAN}

Berdasarkan hasil penelitian yang dilakukan, maka dapat ditarik kesimpulan bahwa pemberdayaan masyarakat desa Kemiri sebelum adanya dana desa memang belum mampu dirasakan oleh masyarakat secara keseluruhan. Selain itu, keadaan infrastruktur sebagai salah satu penunjang akan kegiatan pertumbuhan masyarakat dalam berbagai bidang, keadaannya belum begitu baik. Hal ini dapat dilihat dari keadaan beberapa jalan penghubung antar desa dibeberapa wilayah yang masih rusak, begitu juga jembatan, serta belum ada pembangunan-pembangunan yang ditujukan untuk meningkatkan pemberdayaan masyarakat. Setelah adanya dana desa, masyarakat mulai merasakan dampak yang positif salah satunya yaitu kerjasama pemerintah dan masyarakat dalam peningkatan pembangunan sarana dan prasarana desa seperti pembangunan jalan, jembatan, gorong-gorong, tembok penahan tanah, perbaikan fasilitas desa, sarana pendidikan, sarana kesehatan, dan kegiatan pemberdayaan yang bertujuan meningkatkan perekonomian masyarakat desa Kemiri.

Upaya yang dilakukan Pemerintah desa Kemiri dalam meningkatkan pemberdayaan masyarakat setelah adanya dana desa sudah bagus, perubahan-perubahan serta perbaikan coba dilakukan. Sejauh ini, yang menjadi fokus utama pemerintah desa Kemiri adalah bidang pembangunan yakni pembangunan infrastruktur, pembangunan jalan, jembatan, gorong-gorong dan perbaikan sarana kesehatan dan pen- 
didikan terutama pendidikan PAUD. Pada tahun 2020 Pemerintah Desa Kemiri akan lebih mengedepankan pemberdayaan masyarakat daripada pembangunan infrastruktur, hal ini dikarenakan untuk mengembangkan SDM masyarakat desa kemiri agar bisa berkembang dan menjadi desa yang mandiri dan maju.

\section{PUSTAKA ACUAN}

Abbas, A. (2012). Sistem Ekonomi Islam: Suatu Pendekatan Filsafat, Nilai-Nilai Dasar, Dan Instrumen. Jurnal Ilmiah Ekonomi Islam Al-Iqtishad, 4(115-116).

Kaloh, J. (2007). Mencari bentuk otonomi daerah: suatu solusi dalam menjawab kebutuhan lokal dan tantangan global. Rineka Cipta.

M. Anwas, O. (2014). Pemberdayaan Masyarakat Di Era Global. Alfabeta.

Manjta, W. (2005). Entografi: Desain Penelitian Kualitatif Dan Manajemen Pendidikan. Wineka Media.

Masitoh, \& Laksmi Dewi. (2009). Strategi Pembelajaran. DEPAG RI.

Moleong, L. J. (2012). Metodologi Penelitian Kualitatif. PT. Remaja Rosdakarya.

Nurman. (2015). Strategi Pembangunan Daerah. Raja Grafindo Persada.

Suharto, E. (2014). Membangun Masyarakat Memberdayakan Rakyat (Kajian Strategis Pembangunan Kesejahteraan Sosial Rakyat Dan Pekerjaan Sosial. PT. Refika Aditama.

Sulistiani, A. T. (2004). Kemitraan Dan Model-Model Pemberdayaan. Gava Media.

Supriadi, D., \& Dadang Sholihin. (2003). Otonomi Penyelenggaraan Pemerintah Daerah. Gramedia Pustaka Utama.

Sutoro, E. dkk. (2016). Dana Desa Untuk Desa Membangun Indonesia. Kementrian Desa, Pembangunan Daerah Tertinggal, dan Transmigrasi Republik Indonesia.

Zubaedi. (2013). Pengembangan Masyarakat : Wacana Dan Praktik. Kencana. 